\title{
EARLY PALEOGENE OVERBANK DEPOSITIONAL PATTERNS IN THE HANNA BASIN AND COMPARISON WITH COEVAL STRATA IN THE BIGHORN BASIN (WYOMING, U.S.A.)
}

CHRISTINE SHONNARD, Beloit College

Research Advisor: Jay Zambito

\section{INTRODUCTION}

During the Laramide Orogeny a series of intermontane basins developed in the Rocky Mountain region, the strata of which record the local uplift and paleoclimate history (Dickinson et al., 1988; Aziz et al., 2008; Abels et al., 2013, 2016). This study focuses on two of these basins; the well studied Bighorn Basin in northwestern Wyoming and the relatively understudied Hanna Basin of south-central Wyoming. Both contain distinctive patterns of early Paleogene alluvial deposition including fluvial sandbodies and a variety of floodplain lithofacies (Aziz et al., 2008; Abels et al., 2013, 2016; Kraus and Gwinn, 1997; Wroblewski 2002; Dechesne et al., in review). The well-studied Willwood Formation of the Bighorn Basin contains weakly developed red-bed paleosols stacked between sandy fluvial avulsion deposits (Abels et al., 2013; Fig. 1). Similarly, the Hanna Formation of the Hanna Basin is notable for its repetitive patterns of sandrich units interbedded with finer organic-rich shales, siltstones, and carbonaceous strata (Dechesne et al., in review; Fig. 1). This project will analyze depositional cycles in the Hanna Formation, and compare these to those of the Bighorn Basin in order to reveal any common depositional patterns and hypothesize on their potential controls. While separating allogenic and autogenic controls of cyclical sedimentation patterns in fluvial settings is a difficult task (Abels et al., 2013), comparing patterns in these two basins could illuminate whether there were local, regional, or even global climatic controls on basin deposition during this time.

\section{BACKGROUND}

Sedimentary depositional cycles are not unique to the Hanna Basin - in the well-studied Paleocene-Eocene deposits of the Bighorn Basin alternating deposits of paleosols, formed on a river floodplain during times of river stability, and fluvial avulsion deposits, deposited when the river searches for a new channel bed, have been identified in the Willwood Formation (Kraus and Gwinn, 1997) (Fig. 1). The cause of this river stability and instability is debated - it has been attributed to being autogenic floodplain development cycles in which stable floodplain deposits are preserved as mature paleosols and avulsion periods are preserved as immature paleosols interbedded with sheet sandstones (Clyde and Christensen, 2003). Such autogenic causes of floodplain-avulsion cycles can be difficult to separate from allogenic causes, such as tectonic or climatic changes which drive changes in river morphology through uplift or changes in precipitation (Hajek et al., 2012; Abels et al., 2013; Foreman, 2014).

A number of previous studies have analyzed the stratigraphy, color spectra, inorganic carbon isotopic values from soil carbonate nodules, and geochemistry of the depositional cycles in the Willwood Formation (Aziz et al., 2008; and Abels et al., 2013, 2016). These studies suggested that the duration of the depositional cycles were linked to Milankovitch cyclicity. For example, Abels et al. (2013) concluded that avulsion cycles are basically an autogenic process triggered by flooding, whose periodicity is affected by precession-scale astronomical climate cycles. The repetitive patterns in overbank deposition and 


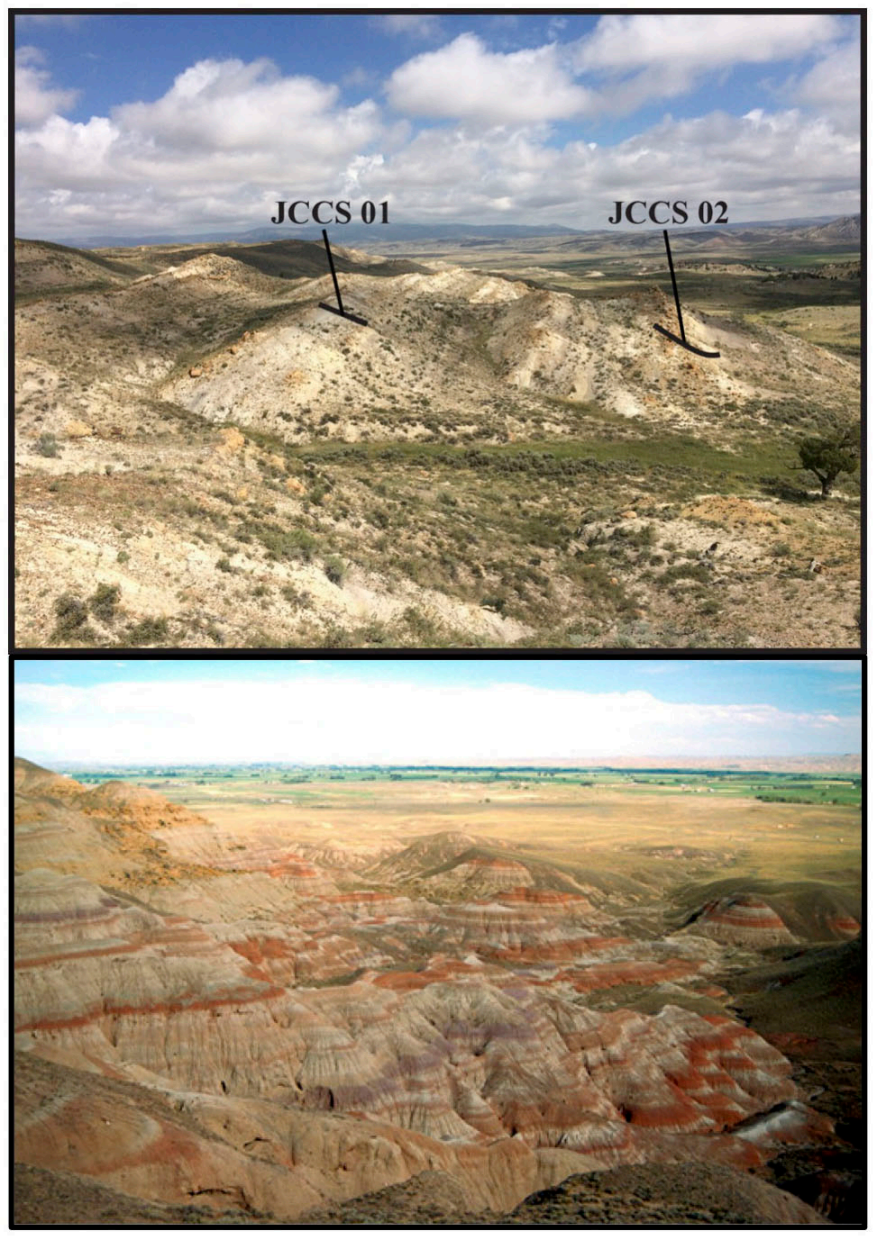

Figure 1. Top: Section Overview of the Leg 17 area of the Hanna Basin, showing the locations of the two stratigraphic sections JCCS-01 and JCCS-02 and the characteristic cyclical deposition of Leg-17. Picture facing towards the south-east (photo by Dr. Jay Zambito). Bottom: Overview of Polecat Bench, including the Willwood Formation, Bighorn Basin (photo by Dr. Will Clyde).

floodplain lithofacies in the Hanna Basin are an ideal setting for evaluating and testing this hypothesis in a different basin.

\section{Geologic Setting}

The study area is part of the Leg 17 section of the Hanna Formation in the Hanna Basin, of Wyoming (Fig. 1). The original Leg 17 section was first measured by Lillegraven (1994), and an updated section, including isotopes and paleobotanical analyses was completed by Dechesne et al. (in review). The Hanna Formation is Paleocene-Eocene in age (roughly 59-54 million years old) (Wroblewski, 2002; Dechesne et al., in review). The Leg 17 section has characteristic cycles of lacustrine, paludal, and fluvial depositional environments, bounded by ledge-

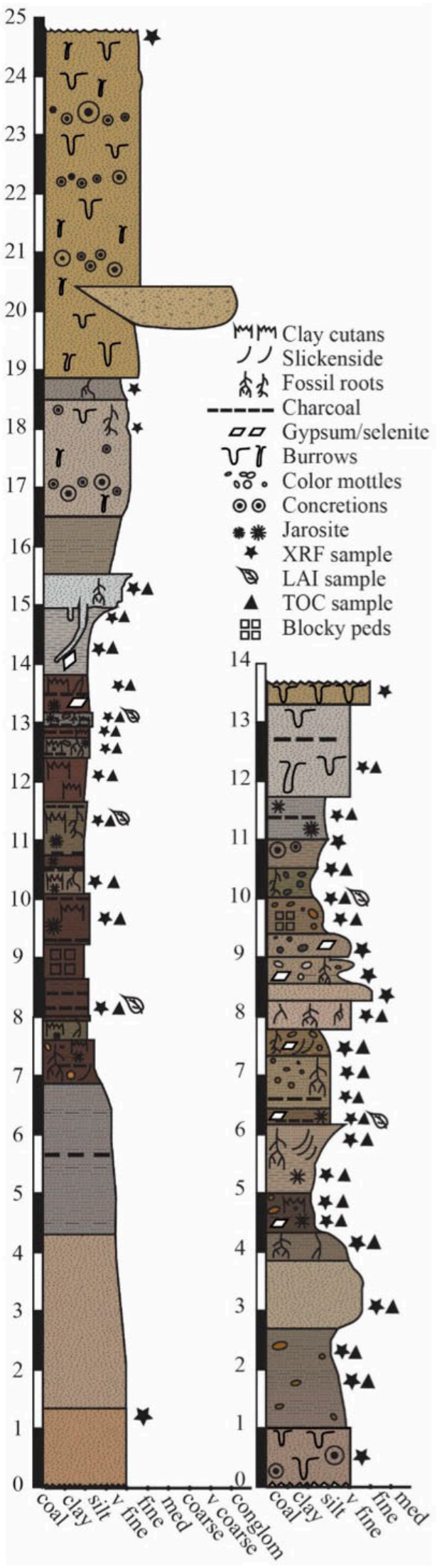

Figure 2. Stratigraphic sections of JCCS-01(right) and 02(left), showing unit thicknesses, changes in lithology, and features. 

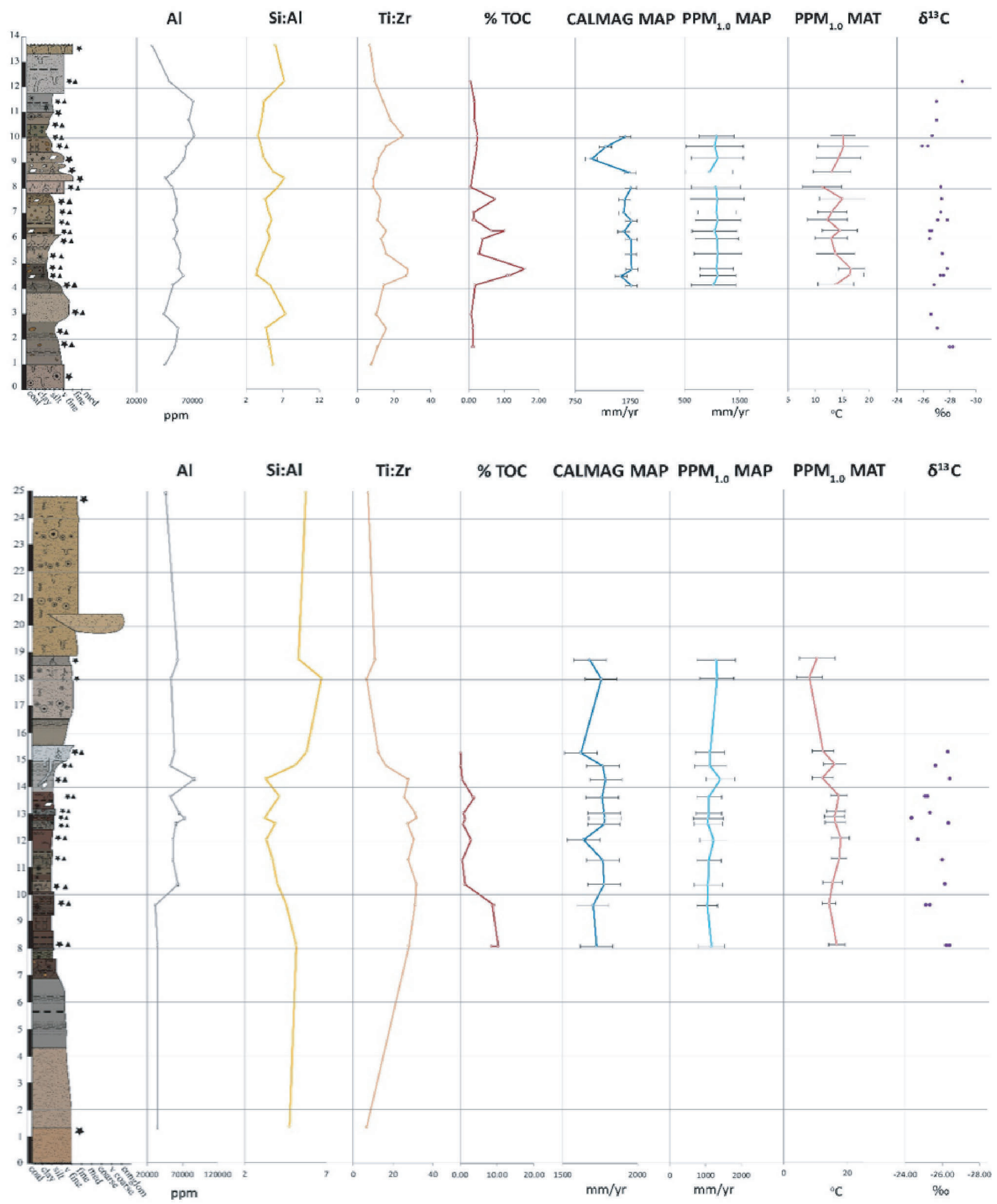

Figure 3. The changes in lithology of sections JCCS-01 and -02 plotted with changes in Al, Si:Al, Ti:Zr, \%TOC, CALMAG MAP, PPM1.0 MAP, PPM1.0 MAT, $\delta^{13}$ C plotted against stratigraphic level. 
forming sandstone units (Fig. 2). This project focuses on two cycles within the Leg 17 section, designated as JCCS-01 and JCCS-02. The sections are located within the earliest Eocene portion of the Hanna Formation, post-dating the PETM as indicated by the presence of Platycarya pollen (Dechesne et al. in review).

\section{METHODS}

\section{Lithological}

Two depositional cycles in the Leg 17 section were deemed relatively representative of the formation by visually approximating their height and lateral consistency (Fig. 1). These cycles, JCCS-01 and JCCS-02, are defined as starting with a ledge forming sandstone unit, proceeding up through interbedded siltstones, carbonaceous shales, and claystones and are capped by an upper ledge-forming sandstone (Fig. 2). The sections were trenched, measured at a high resolution (centimeter-scale), and sampled for total organic carbon, stable carbon isotopes, and geochemical analyses about every $0.5 \mathrm{~m}$. A total of 30 carbon isotope samples were collected, 18 at section JCCS-01, and 12 at section JCCS-02 (Figs. 2 and 3).

\section{Geochemical}

Samples analyzed for both total organic carbon (TOC) and organic stable carbon isotope ratio $\left(\delta^{13} \mathrm{C}\right)$ were prepared by powdering a small piece of each sample, dissolving carbonate material through a series of reactions with $0.5 \mathrm{~N} \mathrm{HCl}$, and rinsing. Small amounts (1-40 mg) of each sample were packaged into tin capsules. This process is similar to that of Baczynski et al. (2013; 2016). The TOC and isotopic composition were analyzed at UC Davis Stable Isotope Facility using an elemental analyzer (Elemental Vario EL Cube) interfaced to a continuous flow isotope ratio mass spectrometer (PDZ Europa 20-20); precision/ accuracy was assessed using internal standards. All data is reported in standard delta-notation relative to the Vienna Pee Dee Belemnite.

Portable $\mathrm{x}$-ray fluorescence (pXRF) analysis was performed at Beloit College Department of Geology to determine the elemental composition of the samples collected in JCCS-01 (24 samples) and JCCS-02 (16 samples) using a Thermo Fisher Scientific Niton XL3t GOLDD+ Handheld XRF Analyzer (Fig. 3). The rock samples were homogenized with a mortar and pestle prior to $\mathrm{pXRF}$ analysis. The elemental compositions of each sample were standardized using calibration factors developed with eight standards, including those of NIST and the USGS (Rowe et al. 2012).

Elemental data collected using pXRF was used for a variety of environmental proxies. The relative concentrations of $\mathrm{Al}$ (as a proxy for clay), $\mathrm{Ti}: \mathrm{Zr}$ (for sand:clay-sized particles), and Si:Al (for silica) were graphed in relation to their stratigraphic position (Zambito et al., 2017). Additionally, geochemical analysis of bulk oxide ratios in paleosol units can be used to reconstruct ancient climate patterns (Abel et al., 2016). Multiple methods exist, including the CALMAG weathering index developed to reconstruct mean annual precipitation (MAP) for vertisols (clay-rich soils whose dominant features are caused by shrink-swell processes) (Nordt and Driese, 2010). For the CALMAG method, MAP $(\mathrm{mm})=$ $22.69 * \mathrm{CALMAG}-435.8$, and $\mathrm{CALMAG}=\mathrm{Al} 2 \mathrm{O} 3 /$ $(\mathrm{Al} 2 \mathrm{O} 3+\mathrm{CaO}+\mathrm{MgO}) \times 100$, where each oxide is a weight percent. Because some soils in the stratigraphic section contain slickensides and high clay content (Fig. 2), the CALMAG method may be appropriate.

Alternately, the paleosol paleoclimate model (PPM1.0) was developed using paleosols from a wide range of depositional environments and is suitable for ancient climate reconstructions because the model is not dependent on characteristics that would be lost over time (Stinchcomb et al., 2016). This method uses nonlinear spline and a partial least squares regression to reconstruct mean annual temperature (MAT) and MAP using geochemical oxide ratios of paleosols. PPM1.0 is calculated using $\mathrm{Al} 2 \mathrm{O} 3, \mathrm{CaO}$, $\mathrm{MgO}, \mathrm{Fe} 2 \mathrm{O} 3, \mathrm{MnO}, \mathrm{P} 2 \mathrm{O} 5, \mathrm{SiO} 2, \mathrm{ZrO} 2, \mathrm{~K} 2 \mathrm{O}$, and $\mathrm{Na} 2 \mathrm{O}$. Because $\mathrm{Na}$ is not detected by the pXRF, proxy $\mathrm{Na} 2 \mathrm{O}$ values found in the supplementary material of Stinchcomb et al. (2016) were selected for each unit based on soil order and land cover.

\section{RESULTS}

\section{Lithological}

The stratigraphy of section JCCS-01 (13.68 m thick) 
Table 1. $\mathrm{R}^{2}$ values of $\delta^{13} \mathrm{C}$ plotted against to total organic carbon (TOC), CALMAG Mean Annual Precipitation (MAP), $\mathrm{PPM}_{1.0} \mathrm{MAP}$, and PPM $\mathrm{PM}_{1.0}$ Mean Annual Temperature (MAT);

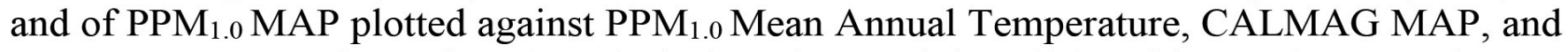
CALMAG MAP using only paleosols (paleosols containing slickensides or clay cutans).

\begin{tabular}{|c|c|c|c|c|c|c|c|}
\hline \multirow{3}{*}{ Section } & \multicolumn{7}{|c|}{$\mathrm{r}^{2}$ value } \\
\cline { 2 - 8 } & \multicolumn{9}{|c|}{$\delta^{13} \mathrm{C}$} & \multicolumn{3}{c|}{ PPM $_{1.0}$ MAP } \\
\cline { 2 - 8 } & TOC (\%) & $\begin{array}{c}\text { CALMAG } \\
\text { MAP }\end{array}$ & $\begin{array}{c}\text { PPM } \\
\text { MAP }\end{array}$ & $\begin{array}{c}\text { PPM } \\
\text { MAT }\end{array}$ & $\begin{array}{c}\text { PPM } \\
\text { MAT }\end{array}$ & $\begin{array}{c}\text { CALMAG } \\
\text { MAP }\end{array}$ & $\begin{array}{c}\text { CALMAG MAP } \\
\text { vertisols only }\end{array}$ \\
\hline JCCS-01 & $4 \times 10^{-7}$ & 0.1783 & 0.4099 & $2 \times 10^{-5}$ & 0.0293 & 0.0173 & 0.2186 \\
\hline JCCS-02 & 0.0004 & 0.0041 & 0.0949 & 0.1159 & 0.4041 & 0.0092 & 0.5361 \\
\hline
\end{tabular}

shows the progression from an orange, heavily bioturbated bottom ledge-forming sandstone into a mottled sandy siltstone layer, another sandstone, six mudstones exhibiting mottling, ancient rootlets, gypsum or selenite crystals, slickensides, and jarosite. Next comes another sandstone layer, a series of four mudstones exhibiting ancient roots, mottling, gypsum, and blocky ped structures, a siltstone with concretions, a sandy siltstone with a charcoal layer and jarosite, a tan bioturbated sandstone, and finally, a second weathered-orange, heavily bioturbated ledge-forming sandstone, which had a similar properties to the lowest sandstone (Fig. 2).

JCCS-02 (24.93 m thick) starts with an orange-grey, massive, ledge-forming sandstone with carbonate cement, a fine-grained light grey sandstone fining into a grey sandy siltstone with charcoal. The next 13 units, spanning $6.9 \mathrm{~m}$, alternate between chocolate brown, fissile, charcoal-rich silty claystones and medium grey blocky claystones, both containing clay cutans, slickensides, fossil roots, mottles, coalified wood, and jarosite. Generally, the chocolate-brown fissile units contained more coalified wood and the blocky grey units contained more ancient rootlets and blocky ped structures. The overlying unit is a coarsening upward grey mudstone, which contains fossil tree roots that penetrate down into underlying layers. The fossil tree roots also contain hematitic liesegang banding and gypsum crystals. Next, a medium grey coarsening upward friable sandy siltstone is overlain by a light yellow-grey very fine grained sandstone containing burrows, a layer of hematite concretions and a liesegang banding which grades into a medium yellow-grey very fine-grained sandstone. The final unit is a thick orange-grey, sandstone heavily bioturbated by burrows 2.5 to $5 \mathrm{~cm}$ in diameter and $\sim 20 \mathrm{~cm}$ in length. The unit contains concretionary cement in places. Laterally, this unit transitions to a channelform containing clasts 1 to $5 \mathrm{~cm}$ in diameter including those of the Jurassic-aged Mowry Shale and dark metamorphic/igneous clasts.

\section{Geochemical}

Concentrations of elements of interest $(\mathrm{Al}, \mathrm{Si}, \mathrm{Ti}$, and $\mathrm{Zr}$ ) collected using $\mathrm{pXRF}$ appear to correlate with inferred mineralogic variations and observed grain size in the lithostratigraphic sections (Fig. 3). For example, in both sections, $\mathrm{Al}$ and $\mathrm{Ti}$ show the same trends and correlate with clay content. Si and $\mathrm{Si}: \mathrm{Al}$ (an estimate of "clayeyness"; Sheldon and Tabor, 2009) have the same patterns in both sections, indicating that the $\mathrm{Si}$ concentrations are dominated by sand-sized silica quartz rather than silicon in clay minerals. $\mathrm{Zr}$ increases in sand-rich and Si-rich units whereas Ti and $\mathrm{Al}$ increase within the clay-rich units. Potentially $\mathrm{Ti}$ is reflecting a greater proportion of fine-grained rutile in these lithofacies.

The $\delta^{13} \mathrm{C}$ values range between about -24\%o and -28\%o and show minor, structured fluctuations up-section, which are especially well-developed in JCCS-01 (Fig. 3). The lowest $\delta^{13} \mathrm{C}$ values roughly occur with the higher \% TOC levels and finer-grained lithofacies. However, the covariation does not appear significant when larger data sets are considered (see Chisholm contribution to this volume).

\section{Climate Estimates}

The PPM1.0 MAT reconstruction from individual beds 
yielded a mean value of $14.14^{\circ} \mathrm{C} \pm 3.4$ (the average of the uncertainties in each individual measurement) and a range of $5.4^{\circ} \mathrm{C}$ in JCCS-01. The mean PPM1.0 MAT for JCCS-02 is $14.74^{\circ} \mathrm{C} \pm 3.3$ with a range of $9.2^{\circ} \mathrm{C}$ (Fig. 3). The mean PPM1.0 MAP reconstruction in JCCS-01 is $106.92 \pm 41.6 \mathrm{~cm} / \mathrm{yr}$ and the range is $15.6 \mathrm{~cm} / \mathrm{yr}$. In JCCS-02, the mean PPM1.0 MAP is $115.91 \pm 40.5 \mathrm{~cm} / \mathrm{yr}$, and the range is $36.2 \mathrm{~cm} / \mathrm{yr}$ (Fig. $3)$. In JCCS-01, the mean of the CALMAG MAP reconstruction is $163.24 \pm 10.8 \mathrm{~cm} / \mathrm{yr}$ and the range is $73.1 \mathrm{~cm} / \mathrm{yr}$. In JCCS-02, the mean CALMAG MAP is $170.49 \pm 10.8 \mathrm{~cm} / \mathrm{yr}$, and the range is $16.5 \mathrm{~cm} / \mathrm{yr}$ (Fig. $3)$. There appears to be weak to no correlation with lithology for each climatic parameter in either section.

Overall the pairwise paleo-precipitation reconstructions, CALMAG and PPM1.0 MAP, are uncorrelated, but when only considering units exhibiting slickensides or clay cutans (paleosols more like vertisols), the relationship is slightly strengthened $\left(\mathrm{R}^{2}=0.2186\right.$ in JCCS-01 and 0.5361 in JCCS-02)

(Table 1). The paleo-precipitation reconstructions are uncorrelated with $\delta^{13} \mathrm{C}$ values (for $\delta^{13} \mathrm{C}$ vs. CALMAG MAP, $\mathrm{R}^{2}=0.1783$ in JCCS- 01 and $\mathrm{R}^{2}=0.0041$ in JCCS-

Table 2. A comparison of MAP and MAT values from the Hanna and Bighorn Basins collected through geochemical and paleo-botanical methods (leaf area analysis = LAA, and leaf margin analysis $=$ LMA)

\begin{tabular}{|c|c|c|c|c|c|c|}
\hline Basin & Location & MAP $(\mathrm{cm} / \mathrm{yr})$ & Method & $\operatorname{MAT}\left({ }^{\circ} \mathrm{C}\right)$ & Method & $\begin{array}{l}\text { Estimated m } \\
\text { level to L17 }\end{array}$ \\
\hline \multirow{5}{*}{$\begin{array}{l}\text { Hanna } \\
\text { Basin }\end{array}$} & Eocene $\mathrm{D}^{\mathrm{a}}$ & $\begin{array}{c}108+46.9,- \\
32.7\end{array}$ & LAA & $21.9 \pm 3.8$ & LMA & 180 \\
\hline & Eocene $E^{b}$ & $\begin{array}{c}132+56.9,- \\
39.7\end{array}$ & LAA & $19.1 \pm 3.7$ & LMA & 376 \\
\hline & JCCS-01 & $\begin{array}{c}163.24 \pm 10.8 \\
106.92 \pm 41.6^{c}\end{array}$ & $\begin{array}{c}\text { CALMAG } \\
\text { PPM }_{10}\end{array}$ & $\begin{array}{l}14.14 \pm \\
3.4^{\mathrm{c}}\end{array}$ & $\begin{array}{l}\text { MAT } \\
\text { PPM }_{10}\end{array}$ & 270 \\
\hline & \multirow{2}{*}{ JCCS-02 } & $170.49 \pm 10.8$ & CALMAG & $\frac{3.4}{14.74 \pm}$ & MAT & \multirow[t]{2}{*}{220} \\
\hline & & $115.91 \pm 40.5^{\mathrm{c} .}$ & $\mathrm{PPM}_{1.0}$ & $3.3^{\mathrm{c}}$ & $\mathrm{PPM}_{1.0}$ & \\
\hline \multirow{6}{*}{$\begin{array}{c}\text { Bighorn } \\
\text { Basin }\end{array}$} & $\begin{array}{l}\text { Elk Creek } \\
\text { Section }{ }^{\text {i. }}\end{array}$ & & & $16.4 \pm 2.7^{\mathrm{d}}$ & LMA & \multirow{6}{*}{ N/A } \\
\hline & $\begin{array}{l}400-k y \\
\text { after the } \\
\text { PETM }\end{array}$ & & & $\begin{array}{c}18.2 \pm 2.3 \\
\text { h. }\end{array}$ & LMA & \\
\hline & \multirow{3}{*}{ PETM } & $\begin{array}{c}\text { Lower flora: } 80 \\
+114,-56 \text { and } \\
41^{\mathrm{h}}\end{array}$ & LAA & $20.1 \pm 2.8^{\mathrm{c}}$ & LMA & \\
\hline & & $\begin{array}{l}\text { Upper flora: } \\
144+206,-100 \\
\text { and } 132^{\mathrm{h} .}\end{array}$ & LAA & $26^{g}$. & $\begin{array}{c}\text { Apatite } \\
\text { Oxygen } \\
\text { isotope } \\
\text { composition }\end{array}$ & \\
\hline & & $123+177,-86^{h}$ & LAA & $19.8 \pm 3.1^{\text {h. }}$ & LMA & \\
\hline & $\begin{array}{c}\text { Latest } \\
\text { Paleocene }\end{array}$ & $173+75,-52^{\mathrm{f}}$ & LAA & $16.4 \pm 2.9^{\mathrm{d}}$ & LMA & \\
\hline \multicolumn{7}{|c|}{$\begin{array}{l}\text { a. Site D location is just after the PETM, } 40 \mathrm{~m} \text { below JCCS-02. (Azevedo Schmidt, 2018). } \\
\text { b. Site E is about } 100 \mathrm{~m} \text { above JCCS-01. (Azevedo Schmidt, 2018). } \\
\text { c. The upper and lower limit values for PPM1.0 were calculating by taking the average of the } \\
\text { differences between the high and low estimates and the best estimate. } \\
\text { d. Wing et al., } 2000\end{array}$} \\
\hline \multicolumn{7}{|c|}{ e. Wing et al., 2006} \\
\hline \multicolumn{7}{|c|}{ f. Diefendorf et al., 2015} \\
\hline \multicolumn{7}{|c|}{ Fricke et al., 2004} \\
\hline \multicolumn{7}{|c|}{ h. Wing et al., 2005} \\
\hline
\end{tabular}

02; for $\delta^{13} \mathrm{C}$ vs. PPM1.0 MAP, $\mathrm{R}^{2}=0.4099$ in JCCS-01 and $\mathrm{R}^{2}=0.0949$ in JCCS-02) (Table 1). There is no meaningful correlation between the PPM1.0 MAT reconstruction and $\delta^{13} \mathrm{C}\left(\mathrm{R}^{2}=2 \times 10-5\right.$ in JCCS- 01 and $\mathrm{R}^{2}=0.1159$ in JCCS-02), nor between the PPM1.0 MAT and PPM1.0 MAP values $\left(\mathrm{R}^{2}=0.0293\right.$ in JCCS01 and $\mathrm{R}^{2}=0.4041$ in JCCS-02) (Table 1).

\section{DISCUSSION \& CONCLUSIONS}

The lithologic and geochemical datasets suggest a structured pattern to overbank deposition; stratigraphic zones marked by bioturbated, orange, tabular sandbodies are overlain by fine-grained units with varying degrees of soil development and organic matter preservation. Two such depositional "cycles", one $\sim 5$ meters thick and a second $\sim 4$ meters thick, are observed in JCCS-01. Section JCCS-02 documents one definitive cycle of $\sim 15$ meters thick, and a second potential cycle $\sim 4 \mathrm{~m}$ thick. The overall depositional environment is interpreted as palustrine with varying degrees of siliciclastic input and standing water. Sandstones display characteristics similar to those of marginal lacustrine environments and crevasse splays may record conduits for sediment and water to the more distal floodplains. Siltstones and claystones with evidence of bioturbation by roots and high organic content are likely more distal portions of the floodplain, and the lithofacies that display the greatest amounts of coal and fissility more distal portions subject to standing water and anoxic marshlike conditions. Other cycles in the complete Leg 17 stratigraphic section show thickness variation of similar scale, and an average thickness of about 10 meters. Up-section variability in these channels could be caused by shrinking and expanding of overbank palustrine environments due to relative changes in water and/or sediment supply related to overall climatic conditions in the basin or more stochastic components of the sediment transport system. Additionally, they may mark periods of avulsion (recorded by sandstones) and relative stability of the main fluvial channels in the basin (recorded by coalrich, fine-grained units).

Comparing our results with lithologic variations in the well-studied Bighorn Basin can help evaluate these processes as well as assess a climatic driver in 
light of the geochemical-based estimates provided in the Hanna Basin. Previous studies in the Willwood Formation recognized two scales of overbank cycle thicknesses, $\sim 8$ meters and $\sim 3$ meters thick (Aziz et al., 2008; Abels et al., 2013). As noted previously these cycles are defined by two packages of overbank deposition: heterolithic, sand-dominated units indicative of crevasse splays and variably redmottled paleosols in siltstones and claystones (Abels et al., 2013). The crevasse splay and soil units are clearly associated with multiple fluvial sandstone channels (Kraus and Middleton, 1987; Foreman, 2014). Overall the observed cycles in the Willwood Formation (ranging from 4.5 to $\sim 10 \mathrm{~m}$ thick) appear to be comparable to or slightly thinner than the Hanna cycles (ranging from $\sim 4$ to $\sim 15 \mathrm{~m}$ thick) (Abels et al., 2013). The major difference appears to be the difference between poorly-drained, palustrine overbank conditions (Hanna Formation) and welldrained, strongly pedogenically-modified overbank conditions (Willwood Formation). This could be due to differences in the rate of sediment supply relative to subsidence in each basin or the overall climate in each.

Table 2 shows a summary of major proxy-based paleoclimate estimates from each basin. The estimates reflect different proxy approaches to estimating MAT and MAP. Early Eocene paleofloral (Azevedo Schmidt, 2018) and geochemical estimates (this study) document largely overlapping MAP estimates with a large degree of variability, but geochemical proxy records appear to under-predict MAT relative to paleofloral records (Table 2). Estimates of MAT between the basins appear insufficient to establish major differences in climate between the two. Early Eocene and Late Paleocene estimates in the Bighorn Basin are similar to those estimated by the PPM1.0 method in the Hanna Basin, but paleofloral records in the Hanna Basin suggest a warmer overall climate during the Eocene that experienced MAT more similar to PETM conditions in the Bighorn Basin (Table $2)$. At the present time it is unclear which is more representative. Note that PPM1.0 does not take the effects of diagenesis into consideration and the units being studied have undergone diagenesis. Based on these datasets we suggest that potentially abnormally rapid subsidence rates in the Hanna Basin (Hajek et al., 2012) may have been responsible for poor floodplain drainage rather than the dominant climate, which has been proposed for some unusually rapidly subsiding areas in the Sevier foreland basin of Utah (Roberts, 2007).

Our datasets offer an initial test of the Abels et al. (2013) and Aziz et al. (2008) hypotheses that the observed avulsion cycles in overbank deposition in the Willwood Formation were related to precessionalscale variability and represent an example of Milankovitch-forcing on alluvial systems. The MAP estimates generated in this study, which show no significant up-section structure from dry to wet (or vice versa) associated with the lithologic cycles, indicate that depositional cycles are unrelated to hydrologic cycle variations driven by Milankovitch parameters. Moreover, the higher sedimentation rates in the Hanna Formation (due to greater subsidence) imply that, although the cycle thickness are mostly similar to the thicknesses in the Willwood Formation, it is likely that the Hanna Basin cycles represent a shorter duration of geologic time (i.e., shorter than the $20 \mathrm{kyr}$ precession timescale). Additionally, the $\delta^{13} \mathrm{C}$ values show no variability up-section correlated with MAT or MAP suggesting meso-scale climate did not play a significant role in cycle deposition. Therefore, this study suggests that the overbank cycles in the Hanna Basin described here are largely driven by autogenic processes, which have been shown to create cyclical stratigraphy in model systems (Jerolmack and Paola, 2007; Sheets et al., 2007; Hajek et al., 2010). Additional outcrop and geochemical analyses will be needed to test this hypothesis with larger datasets.

\section{ACKNOWLEDGEMENTS}

This material is based upon work supported by the Keck Geology Consortium and the National Science Foundation under Grant No. 1659322 as well as NSF grant EAR 145031 to Ellen Currano. I would like to thank all of those involved in the Keck 2018-19 research project: advisors and mentors Ellen Currano, Brady Foreman, Marieke Dechesne, Regan Dunn, and Jay Zambito, as well as student colleagues James Chisholm, Jake Polsak, Xavier Nogueira, Keifer Nace, and Anthony Semeraro. 


\section{REFERENCES}

Abels, H. A., Kraus, M. J., and Gingerich, P. D., 2013, Precession-scale cyclicity in the fluvial lower Eocene Willwood Formation of the Bighorn Basin, Wyoming (USA): Sedimentology, v. 60, p. 1467-1483, doi: 10.1111/sed.12039.

Abels. H. A., Lauretano, van Yperen, A. E., Hopman, T., Zachos, J. C., Lourens, L. J., Gingerich, P. D., and Bowen, G. J., 2016, Environmental impact and magnitude of paleosol carbonate carbon isotope excursions marking five early Eocene hyperthermals in the Bighorn Basin, Wyoming: Climate of the Past, v. 12, p. 1151-1163, doi: 10.5194/cp-12-1151-2016.

Azevedo Schmidt, L. E., 2018. The effects of depositional environment on plant and insect herbivore communities across the PaleoceneEocene Boundary, Hanna Basin WY. MS Thesis. University of Wyoming, Laramie, WY.

Aziz, H. A., Hilgen, F. J., van Lujik, G., M., Sluijs, A., Kraus, M. J., Pares, J. M., and Gingerich, P. D., 2008, Astronomical climate control on paleosol stacking patterns in the upper Paleocene-lower Eocene Willwood Formation, Bighorn Basin, Wyoming: Geology, v. 36, no. 7, p. 531-534; doi: 10.1130/G24734A.1.

Bush, R. T., Wallace, J., Currano, E. D., Jacobs, B. F., McInerney, F., A., Dunn, R. E., and Tabor, N. J., 2017, Cell anatomy and leaf $\delta^{13} \mathrm{C}$ as proxies for shading and canopy structure in a Miocene forest from Ethiopia: Palaeogeography, Palaeoclimatology, Palaeoecology, v. 485, p. 593604, doi: 10.1016/j.palaeo.2017.07.015.

Clyde, W. C., and Christensen, K. E., 2003, Testing the relationship between pedofacies and avulsion using Markov analysis: American Journal of Science, v. 303:1, p. 60-71, doi: 10.2475/ ajs.303.1.60.

Currano, E. D., Wilf, P., Wing, S. L., Labandeira, C. C., Lovelock, E. C., and Royer, D. L., 2008, Sharply increased insect herbivory during the Paleocene-Eocene Thermal Maximum: National
Academy of Sciences, 105(6), p. 1960-4, p. 54767, doi: 10.1073/pnas.0708646105.

Currano, E. D., Labandeira, C. C., and Wilf, P., 2010, Fossil insect folivory tracks paleotemperature for six million years: Ecological Society of America, v. 80 (4), doi: 10.1890/09-2138.1.

Dechesne, M., E.D. Currano, E. D., Dunn, R.E., Higgins, P., Hartman, J.H., Chamberlain, K.R., and Holm-Denoma, C.S., In review, Depositional patterns of the fluvial to paludal strata of the Hanna Formation across the Paleocene - Eocene boundary, Hanna Basin, Wyoming.

Dickinson, W. R., Klute, M. A., Hayes, M. J., Janecke, S. U., Lundin, E. R., McKittrick, M. A., and Olivares, M. D., 1988, Paleogeographic and paleotectonic setting of Laramide sedimentary basins in the central Rocky Mountain region: Geologic Society of America Bulletin, v. 100, p. 1023-1039.

Diefendorf, A. F., Freeman, K. H., Wing, S. W., Currano, E. D., Mueller, K. E., 2015, Paleogene plants fractionated carbon isotopes similar to modern plants: Earth and Planetary Science Letters, v. 429, p. 33-44.

Dunn, R. E., Currano, E. D., Dechesne, M., Foreman, B. Z., 2018, Forest canopy response to greenhouse warming at the Paleocene-Eocene Thermal Maximum: Abstract 213-8 presented at Fall Meeting, Geological Society of America, Indianapolis, Indiana, 3-7 November.

Dunn, R. E., Stromber, C. A., Madden, R. H., Kohn, M. J., and Carlini, A. A., 2015, Linked canopy, climate, and faunal change in the Cenozoic of Patagonia: Science v. 347: 6219, p. 258-261, doi: 10.1126/science. 1260947.

Foreman, B. Z., 2014, Climate-driven generation of a fluvial sheet sand body at the PaleoceneEocene boundary in north-west Wyoming (USA): Basin Research, v. 26, p. 225-241, doi: 10.1111/ bre. 12027.

Fricke, H. C., and Wing, S. L., 2004, Oxygen isotope 
and paleobotanical estimates of temperature and

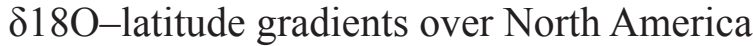
during the early Eocene: American Journal of Science, v. 304, p. 612-635, doi: 10.2475/ ajs.304.7.612.

Hajek, E. A., Heller, P. L., and Schur, E. L., 2012, Field test of autogenic control on alluvial stratigraphy (Ferris Formation, Upper Cretaceous-Paleogene, Wyoming): GSA Bulletin, v. 124, no. 11/12, p. 1898-1912, doi: 10.1130/ B30526.1.

Hajek, E.A., Heller, P.L., and Sheets, B.A., 2010, Significance of channel-belt clustering in alluvial basins: Geolo gy, v. 38, no. 6, p. 535-538, doi:10.1130/G30783.1.

James Cook University, 2018, Advanced Analytical

Centre: Element-to-stoichiometric oxide conversion factors: https://www.jcu.edu.au/ advanced-analytical-centre/services-andresources/resources-and-extras/elementto-stoichiometric-oxide-conversion-factors (accessed January 2019).

Jerolmack, D.J., and Paola, C., 2007, Complexity in a cellular model of river avulsion: Geomorphology, v. 91, no. 3-4, p. 259-270, doi:10.1016/j. geomorph.2007.04.022.

Sheets, B.A., Paola, C., and Kelberer, J.M., 2007, Creation and preservation of channel-form sand bodies in an experimental alluvial system, in Nichols, G.J., Williams, E., and Paola, C., eds., Sedimentary Processes, Environments and Basins: International Association of Sedimentologists Special Publication 38, p. 555-567.

Jones, J. A., Creed, I. F., Hatcher, K. L., Warren, R. J., Adams, M. B., Benson, M. H., Boose, E., Brown, W. A., Campbell, J. L., Covich, A., Clow, D. W., Dahm, C. N., Elder, K., Ford, C. R., Grimm, N. B., Henshaw, D. L., Larson, K. L., Miles, E. S., Miles, K. M., Sebestyen, S. D., Spargo, A. T., Stone, A. B., Vose, J. M., and Williams, M. W., 2012, Ecosystem Processes and Human Influences Regulate Streamflow Response to Climate Change at Long-Term Ecological Research Sites: BioScience, v. 62, no. 4, p. 390404, doi: 10.1525/bio.2012.62.4.10.

Karageorgis, A. P., Kaberi, H., Price, N. B., Muir, G. K., Pates, J. M., and Lykousis, V., 2005, Chemical composition of short sediment cores from Thermaikos Gulf (eastern Mediterranean); sediment accumulation rates, trawling and winnowing effects: Continental Shelf Research, v. $25: 19$, p. $2456-2475$, doi: $10.1016 /$ j. csr.2005.08.006.

Keck Geology Consortium, 2017, Assessing vegetation and fluvial responses to the PETM: https://keckgeology.org/2017/12/wyoming2018/ (accessed December, 2018).

Kowalski, B., Dilcher, D., 2003, Warmer paleotemperatures for terrestrial ecosystems: Proceedings of the National Academy of Sciences of the USA, v. 100 (10), p. 167-170, doi: $10.1073 /$ pnas.232693599.

Kraus, M. J., and Riggins, S., 2006, Transient drying during the Paleocene-Eocene Thermal Maximum (PETM): Analysis of paleosols in the bighorn basin, Wyoming: Palaeogeography, Palaeoclimatology, Palaeoecology, v. 245, p. 444461, doi:10.1016/j.palaeo.2006.09.011.

Kraus, M. J., 1999, Paleosols in clastic sedimentary rocks: their geologic applications: Earth-Science Reviews, v. 47, p. 41-70.

Kraus, M.J., and Middleton, L.T., 1987, Contrasting architecture of two alluvial suites in different structural settings. In: Recent Developments in Fluvial Sedimentology (Ed. by F.G. Ethridge) Soc. Econ. Paleo. Mineral. Spec. Pub., v. 30, p. 253-262.

Kraus, M. J., and Gwinn, B. M., 1997, Facies and facies architecture of Paleogene floodplain deposits, Willwood Formation, Bighorn Basin, Wyoming, USA: Sedimentary Geology, v. 114, p. 33-54.

Kraus, M. J., McInerney, F. A., Wing, S. L., 
Secord, R., Baczynski, A. A., and Bloch, J. I., 2012, Paleohydrologic response to continental warming during the PaleoceneEocene Thermal Maximum, Bighorn Basin, Wyoming: Palaeogeography, Palaeoclimatology, Palaeoecology, v. 370, p. 196-208.

Lillegraven, J. A., 1994, Age of upper reaches of Hanna Formation, northern Hanna Basin, southcentral Wyoming: Berliner geowissenschaftliche Abhandlungen, Reihe E (Paläobiologie), Band 13 (B. Krebs-Festschrift), p. 203-219.

McInerney, F. A., and Wing, S. L., 2011, The Paleocene-Eocene Thermal Maximum: A perturbation of carbon cycle, climate, and biosphere with implications for the future: Annual Review Earth Planetary Sciences, v. 39, p. 489-516.

NOAA National Centers for Environmental information, Climate at a Glance: Statewide Time Series, published February 2019, retrieved on February 28, 2019 from: https://www.ncdc.noaa. gov/cag/.

Nordt, L. C., and Driese, S. D., 2010, New weathering index improves paleorainfall estimates from Vertisols: Geology, v. 38:5, p. 407-10, doi: 10.1130/G30689.1.

Roberts, E.M., 2007, Facies architecture and depositional environments of the Upper Cretaceous Kaiparowits Formation, southern Utah: Sedimentary Geology v, 197, p. 207-233.

Rowe, H., Hughes, N., Robinson, K., 2012, The quantification and application of handheld energy-dispersive $\mathrm{x}$-ray fluorescence (ED-XRF) in mudrock chemostratigraphy and geochemistry: Chemical Geology 324-325, p. 122-131, doi: 10.1016/j.chemgeo.2011.12.023.

Sheldon, N.D., and Tabor, N.J., 2009, Quantitative paleoenvironmentl and paleoclimatic reconstruction using paleosols: Earth-Science Reviews, v. 95, p. 1-52.

Stinchcomb, G.E., Nordt., L. C., Driese, S. G.,
Lukens, W. E., Williamson, F. C., and Tubbs, J. E., 2016, A data-driven spline model designed to predict paleoclimate using paleosol geochemistry: American Journal of Science, v. 316, p. 746-777, doi: 10.2475/08.2016.02.

Wilf, P., Wing, S. L., Greenwood, D. R. \& Greenwood, C. L., 1998, Using fossil leaves as paleoprecipitation indicators. An Eocene example: Geology, v. 26, p. 203-206.

Wing, S. L., Lovelock, E. C., and Currano, E. D., 2006, Climatic and floral change during the PETM in the Bighorn Basin, Wyoming, USA. Climate \& Biota of the Early Paleogene. Bilbao, Spain.

Wing, S. L., Harrington, G. J., Smith, F. A., Bloch, J. I., Boyer, D. M., and Freeman, K. H., 2005, Transient Floral Change and Rapid Global Warming at the Paleocene-Eocene Boundary: Science v. 320, p. 993-996, doi: 10.1126/ science. 1116913.

Wing, S. L., Bao, H., and Koch, P. L., 2000, An early Eocene cool period? Evidence for continental cooling during the warmest part of the Cenozoic. Pp. 197-237. In B. T. Huber, K. G. MacLeod, and S. L. Wing, eds. Warm climates in earth history. Oxford U P, Cambridge).

Wing, S. L., Lovelock, E. C., and Currano, E. D., 2006, Climatic and floral change during the PETM in the Bighorn Basin, Wyoming, USA: Climate \& Biota of the Early Paleogene. Bilbao, Spain.

Wolfe, J. A., 1979, Temperature parameters of humid to mesic forests of Eastern Asia and relation to forests of other regions of the Northern Hemisphere and Australasia: United States Geological Survey Professional Paper, 1106: $1-37$.

Wroblewski, A. 2002. The Role of the Hanna Basin in Revised Paleogeographic Reconstructions of the Western Interior Sea During the CretaceousTertiary Transition. Wyoming Geological Association Guidebook. 2002 Field Conference, 
p. $17-40$.

Zambito, J., McLaughlin, P., and Bremmer, S., 2017, Elemental chemostratigraphy of the Cottage Grove Hole MP-18 core: Implications for lithoand hydrostratigraphy in Wisconsin: Wisconsin Geological and Natural History Survey Open-File Report 2017-03, p. 1-7. 